\title{
B15 Determinação de Eritropoetina Humana Recombinante em amostras do produto final Alfaepoetina humana recombinante por Cromatografia a Líquido de Alta Eficiência
}

\author{
Eduardo da Silva Gomes de Castro ${ }^{1}$, Melissa Chamon Alves Premazzi ${ }^{1}$ \\ ${ }^{1}$ Bio-Manguinhos, Fiocruz, RJ
}

Introdução: A Eritropoetina Humana (EPO) é uma Glicoproteína produzida primariamente pelos rins, a qual regula a produção de células vermelhas no sangue. A eritropoetina humana recombinante (rhEPO) tem sido expressa através da tecnologia de DNA recombinante e diversos preparos farmacêuticos encontram-se disponíveis por fabricantes pelo mundo. Como se trata de uma proteína recombinante, a rhEPO sofre espontâneas modificações estruturais, tais como: desaminação, oxidação e agregação. Desta forma, do ponto de vista do Controle de Qualidade, é de fundamental importância o conhecimento da concentração de rhEPO nas formulações produzidas em Bio-Manguinhos, para a avaliação da estabilidade e qualidade do produto. O desenvolvimento de uma metodologia eficiente para a determinação da substância ativa (rhEPO) pode apresentar algumas dificuldades oriundas principalmente da presença da Albumina Humana usada como excipiente em suas formulações. A presença desta outra proteína inviabiliza a utilização de técnicas como a espectrofotometria de absorção na região do UV/VIS sem uma etapa prévia de separação. Dentro deste contexto insere-se a Cromatografia a Líquido de Alta eficiência (CLAE) como ferramenta imprescindível para a obtenção de uma resolução mínima necessária para a determinação de EPO livre de interferências oriundas da Albumina humana e de outras substâncias eventualmente presentes na formulação que possam vir a coeluir com este analito.

Objetivo: Desenvolver metodologia analítica para a determinação de rhEPO em amostras do biofármaco alfaepoetina humana recombinante nas apresentações 2000, 4000 e 10000 UI.

Metodologia: Durante o desenvolvimento da metodologia, utilizou-se amostras de diferentes lotes do biofármaco alfaepoetina humana recombinante nas 3 apresentações 2000, 4000 e 10000 UI, além do Material de Referência in house de EPO (rHEPO, MRT, lote 0208) para a construção da curva analítica. O equipamento utilizado foi um Cromatógrafo a Líquido de Alta Eficiência (Waters, Alliance), equipado com um detector de UV, modelo 2996. Empregou-se uma coluna analítica do tipo C18, marca Bakerbond, 4,6 x 100nm, $5 \mathrm{~mm}$. Fase móvel "A": Ácido Trifluoracético $0,1 \%$ em água Milli-Q e fase móvel "B": Ácido Trifluoracético $0,1 \%$ em Acetonitrila, modo gradiente, vazão 1,5 $\mathrm{mL} / \mathrm{min}$. 
Resultados: A metodologia proposta apresentou exatidão melhor que 98\% para as apresentações 2000 e 10000 UI e melhor que 96\% para a apresentação $4000 \mathrm{UI}$, quando comparadas com o Material de Referência in house. Além disso, o método se mostrou linear na faixa de $10-50 \mathrm{mg} / \mathrm{mL}$, com coeficiente de determinação $(R 2)>0,999$.

Conclusão: A metodologia proposta mostrou-se vantajosa por apresentar uma boa resolução cromatográfica entre os picos de rhEPO e Albumina Humana, seu principal interferente. Além disso, foi possível observar boas figuras de mérito alcançadas durante a validação, demonstrando assim que o método atende às necessidades do Controle de Qualidade.

Palavras-Chave: rHEPO, CLAE, Biofármacos 